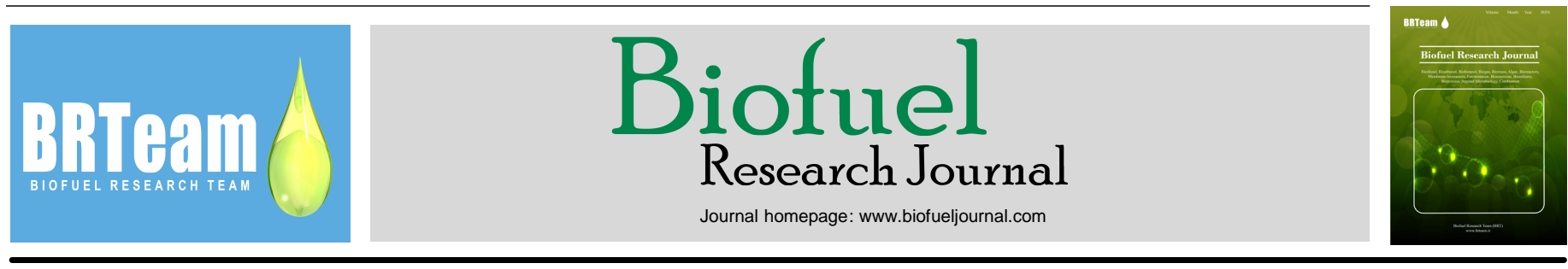

Original Research Paper

\title{
Enhanced dark fermentative biohydrogen production from marine macroalgae Padina tetrastromatica by different pretreatment processes
}

\author{
M. Radha, A.G. Murugesan*
}

Manonmaniam Sundaranar University, Sri Paramakalyani Centre of Excellence in Environmental Science, Alwarkurichi 627 412, Tamil Nadu, India.

\section{HIGHLIGHTS}

$>$ Dilute sulphuric acid pretreatment of Padina tetrastromatica enhanced dark fermentative

biohydrogen production.

$>$ Under optimized conditions, $1 \% \mathrm{v} / \mathrm{v}$ of sulphuric acid pretreatment effectively removed total phenolic content ( $3.4 \pm 0.078$ to $0.06 \mathrm{mg} \mathrm{GAE} / \mathrm{g}$ ).

$>$ Highest cumulative biohydrogen production of 78 $\pm 2.9 \mathrm{~mL} / 0.05 \mathrm{~g}$ VS was achieved.

\section{GRAPHICAL ABSTRACT}

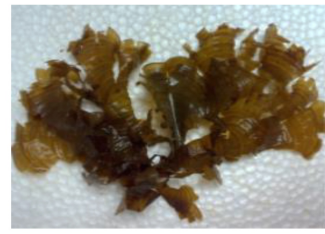

Fresh Seaweed

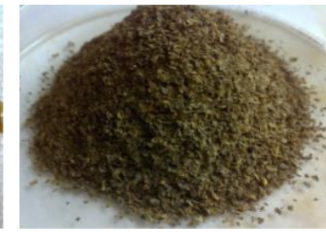

Powdered Seaweed

Clear Sugar Solution

Biohydrogen Fermentation
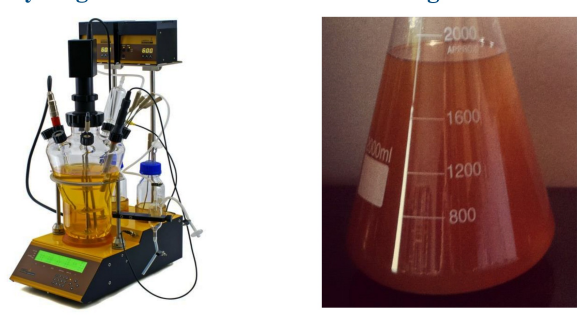

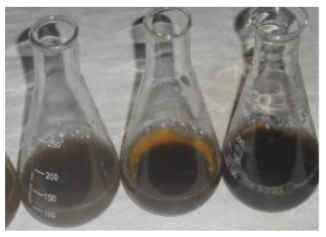

$\mathrm{H}_{2} \mathrm{SO}_{4}$ pretreatment

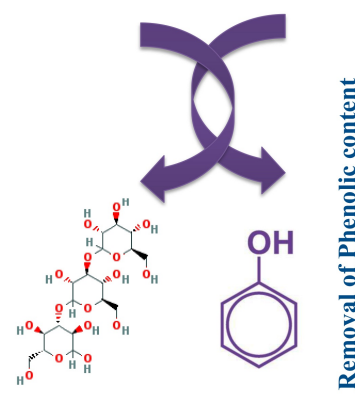

\section{ARTICLE INFO}

\section{Article history:}

Received 26 December 2016

Received in revised form 31 January 2017

Accepted 2 February 2017

Available online 1 March 2017

\section{Keywords:}

Biohydrogen

Dark fermentation

Seaweed

Macroalgae

Padina tetrastromatic

Pretreatment

\begin{abstract}
Marine macroalgae are promising substrates for biofuel production. Pretreating macroalgae with chemicals could remove microbial inhibitors and enhance the accessibility of the microorganisms involved in the process to the substrates leading to increased product yield. In the present study, Padina tetrastromatica a seaweed species was subjected to different chemical pretreatment in order to remove phenolic content and to enhance biohydrogen production. Different mineral acids (i.e., HCl, $\mathrm{H}_{2} \mathrm{SO}_{4}$, and $\mathrm{HNO}_{3}$ ) and bases $(\mathrm{NaOH}$ and $\mathrm{KOH})$ were applied for effective pretreatment of the seaweed. Dilute sulphuric acid treatment of seaweed resulted in the highest cumulative biohydrogen production of $78 \pm 2.9 \mathrm{~mL} / 0.05 \mathrm{~g}$ VS and reduced phenolic content to $1.6 \pm 0.072 \mathrm{mg}$ gallic acid equivalent $(\mathrm{GAE}) / \mathrm{g}$. Optimization of three variables for pretreatment (i.e., substrate concentration, acid concentration, and reaction time) was examined by Response Surface Methodology. After the optimization of the pretreatment conditions, phenolic content was decreased to $0.06 \mathrm{mg} \mathrm{GAE} / \mathrm{g}$. and enhanced biohydrogen production was observed. Structural changes due to pretreatment was studied by FTIR and XRD analyses. The results clearly indicated that the dilute sulphuric acid pretreatment was effective in removing phenolic content and enhancing biohydrogen production.
\end{abstract}

(c) 2017 BRTeam. All rights reserved.

* Corresponding author at: Tel.: 0091-4634283270

E-mail address: agmspkce@rediffmail.com

Please cite this article as: Radha, M., Murugesan A.G. Enhanced dark fermentative biohydrogen production from marine macroalgae Padina tetrastromatica by different pretreatment process. Biofuel Research Journal 13 (2017) 551-558. DOI: 10.18331/BRJ2017.4.1.5 


\section{Introduction}

The search for future renewable and clean energy carriers is increasingly focused on hydrogen mainly due to its environmentally-friendly nature and the fact that it burns clean. Besides, hydrogen has been proven to be an ideal transportation fuel in terms of adaptability and safety (Hallenbeck et al., 2012). Several modes of hydrogen productions have been widely investigated employing various chemicals and biomass resources (Lakshmikandan and Murugesan, 2016a). Among them, biological hydrogen production could be attained by using microalgae as well as photosynthetic and fermentative bacterial strains (Li et al., 2004; Ren et al., 2006). Fermentative biohydrogen production technology is based on the utilization of biomass as raw material to produce fuel hydrogen. Selection of raw materials for large scale biohydrogen production is based on a number of factors including availability, renewability, cost, carbohydrate content, and biodegradability (Kapdan and Kargi, 2006). Cultivation of biomass on land for fuel can lead to negative impacts on food production economy. It has shown that marine resources (e.g., seaweeds and seagrass) could be used as sustainable replacements for food grains in biofuels production (Carlsson, 2007; Vergara-Fernández et al., 2008).

Seaweeds have been used for the production of various biofuels like biogas, bio-ethanol, biohydrogen, and acetone-ethanol-butanol fermentation (van der Wal et al., 2013). Seaweeds can produce a great quantity of biomass within a short period of time. Their growth rate and biomass yield are higher than those of the terrestrial plants. For example, brown seaweeds yields $\sim 13.1 \mathrm{~kg}$ dry weight $/ \mathrm{m}^{2} / \mathrm{yr}$ compared with $\sim 10 \mathrm{~kg}$ dry weight $/ \mathrm{m}^{2} / \mathrm{yr}$ for sugarcane (Rajkumar et al., 2013; Leu and Boussiba, 2014). Other advantages of utilizing seaweeds for biofuel production is the possibility to grow them in seawater as well less energy requirements for production and harvesting. Moreover, seaweed do not contain lignin, and therefore, their carbohydrate content can be readily converted into sugars (Milledge et al., 2014).

Seaweeds naturally have several bioactive compounds including antimicrobials. These bioactive compounds which are mainly phenolic compounds, sulphated polysaccharides, and organic acids (Liu, 2003; Podsędek, 2007), may affect the growth and metabolism of fermentative bacterial strains. They could exert promoting or inhibiting effects on microbial growth depending on their compositions and concentrations (Vaquero et al., 2007). Hence, the removal of phenolic compounds present in seaweeds is one of the most important tasks to achieve a product of interest. To accomplish that, seaweeds are generally pretreated by using chemicals such as acids, bases, or enzymes (Adams et al., 2009; Lu et al., 2009). The biofuels production yields from seaweeds differ significantly depending on the pretreatment applied. (Lakshmikandan and Murugesan, 2016b). Selecting a suitable pretreatment method to increase hydrolysis rate of seaweed is an important task to enhance the digestibility and accessibility of biomass. In the present study, different chemical pretreatment methods were studied with respect to the removal of phenolic content, a well-known fermentation inhibitor presents in the seaweeds, and to enhance biohydrogen productivity.

\section{Materials and Methods}

\subsection{Substrate collection}

The seaweed Padina tetrastromatica was collected from Tuticorin coastal area, Gulf of Mannar biosphere, and south-east coast of India. Samples were manually collected, brought to the laboratory in plastic bags, and washed thoroughly with tap water to remove all impurities, sand particles, and salt. $P$. tetrastromatica was identified and confirmed by SDMRI (Suganthi Devadason Marine Research Institute, Tuticorin, India). The seaweeds were spread out on a paper and shade-dried at room temperature. After drying, the samples were kept in a hot air oven at $60^{\circ} \mathrm{C}$ for $1 \mathrm{~h}$, cut into small pieces, and milled into fine powder. Seaweed powder was stored in an air-tight container at room temperature.

\subsection{Pretreatment studies}

Pretreatment of the seaweed was accomplished with different chemical catalysts. An amount of $1 \% \mathrm{v} / \mathrm{v}$ of three mineral acids $\left(\mathrm{HCl}, \mathrm{H}_{2} \mathrm{SO}_{4}\right.$, and $\left.\mathrm{HNO}_{3}\right)$ and $2 \% \mathrm{w} / \mathrm{v}$ of two bases $(\mathrm{NaOH}$ and $\mathrm{KOH})$ were studied. The experimental conditions were set at $100^{\circ} \mathrm{C}$ for $2 \mathrm{~h}$. The best catalyst was chosen based on the reduction in total phenolic content of the seaweeds before and after pretreatments. Total phenolic content was estimated by folin-ciocalteu method as gallic acid equivalent (GAE).

The optimization of the pretreatment conditions for the removal of phenolic content and simultaneous biohydrogen production was carried out for the best catalyst by using the statistical software Design Expert 7.0.0 (Stat-Ease-Inc. Mineapolis, USA). Central Composite Design was constructed for three different variables, i.e., A: Substrate Concentration (\% w/v), B: Catalyst Concentration (\% v/v), and C: Reaction Time. Coded levels were set as optimum $($ Code $=0)$, Minimum $($ Code $=-1)$, and Maximum $($ Code $=+1)($ Table 1$)$.

Table 1.

Illustration of coding levels involved in the optimization of pretreatments.

\begin{tabular}{|c|c|c|c|c|}
\hline \multirow{2}{*}{ Independed variables } & \multirow{2}{*}{ Symbols } & \multicolumn{3}{|c|}{ Coded levels } \\
\hline & & -1 & $\mathbf{0}$ & 1 \\
\hline Substrate concentration $(\mathrm{g} / \mathrm{L})$ & A & 1 & 2 & 3 \\
\hline Catalyst concentration $\%(\mathrm{v} / \mathrm{v})$ & B & 0.5 & 1 & 1.5 \\
\hline Reaction time (h) & $\mathrm{C}$ & 0.5 & 1 & 0.5 \\
\hline
\end{tabular}

Two responses were set as Total Phenolic content (mg GAE/g) and Biohydrogen Production $(\mathrm{mL} / \mathrm{L} / \mathrm{h})$. In performing the regression equation, the test variables were coded according to Equation 1.

$\mathrm{Xi}=\mathrm{X}-\mathrm{Xi} / \Delta \mathrm{Xi}$

(Eq. 1)

Based on the central composite design, 20 experiments were generated to determine the experimental values of each factor. The interactions among various factors were interpreted by 3D response graphs and the optimized value of each factor was analysed. From the analytical data, 3D curves and quadratic equation were developed by using the following equation (Eq. 2):

$\mathrm{Y}=\beta_{0}+\beta_{1} A+\beta_{2} B+\beta_{3} C+\beta_{1} \beta_{1} A^{2}+\beta_{2} \beta_{2} B^{2}+\beta_{3} \beta_{3} C^{2}+\beta_{1} \beta_{2} A B+\beta_{1} \beta_{3} A C+\beta_{2} \beta_{3} B C$

where $\mathrm{Y}$ is the predicated value, $A, B$, and $C$ are the coded independent variables, $\beta_{1} \beta_{1}, \beta_{2} \beta_{2}$, and $\beta_{3} \beta_{3}$ represent the quadratic coefficients, $\beta_{1} \beta_{2}, \beta_{1} \beta_{3}$, and $\beta_{2} \beta_{3}$ are the interactive coefficients, $\beta_{1}, \beta_{2}$, and $\beta_{3}$ denote the linear coefficients, while $\beta_{0}$ stand is a constant.

\subsection{Isolation and identification of seed inoculums for biohydrogen production study}

Seed inoculums were prepared from the isolated bacterial colonies obtained from the sewage sludge (Alwarkurichi municipality, Tirunelveli, Tamil Nadu, India). The collected sample had a $\mathrm{pH}$ of $6.05 \pm 0.5$, a TDS of $86.7 \pm 1.7 \%$, and had a temperature of $26 \pm 2^{\circ} \mathrm{C}$. Sludge was heat-treated for $10 \mathrm{~min}$ at $60^{\circ} \mathrm{C}$ to inhibit the vegetative cells (Bala-Amutha and Murugesan, 2013). The pretreated sludge was poured into $100 \mathrm{~mL}$ of the sodium alginate medium containing peptone $0.05 \mathrm{~g}$; yeast extract $0.03 \mathrm{~g} ; \mathrm{KH}_{2} \mathrm{PO}_{4}$ $0.1 \mathrm{~g}, \mathrm{MgSO}_{4} 0.05 \mathrm{~g}$; sodium alginate $0.5 \mathrm{~g}$; and $\left(\mathrm{NH}_{4}\right)_{2} \mathrm{SO}_{4} 0.2 \mathrm{~g}$; and was incubated at $37^{\circ} \mathrm{C}$ at $\mathrm{pH}$ 6.0. Predominant colonies were re-streaked on the same medium and purified.

Matrix-assisted laser desorption ionization time-of-flight (MALDITOF) mass spectrometry was used for the identification of the bacteria based on their peptide spectrum (Seng et al., 2009). Twenty-four h fresh cultures were identified in Bruker Daltonik MALDI Biotyper. More specifically, one single colony was directly placed on a MALDI-TOF target plate (Bruker Daltonik MALDI Biotyper) and the colony was covered with $2 \mathrm{~mL}$ of matrix solution. Measurements were performed by the flex control method of MBT. Spectra were recorded in the linear acquisition mode. Each spectrum was obtained after 280 shots in the automatic mode at a variable laser power. Data were automatically acquired using the acquisition control software. The spectra obtained for each isolate were imported into BioTyper software, version 2.0 (Bruker, Daltonik), and were analysed by standard pattern matching against the spectra of stored species. The score value for identification of each sample was analysed and the species exhibiting the most similar peptide pattern with the isolate were 
ranked by their identification score. Based on the score value, bacterial genus and species were identified and tabulated.

\subsection{Experimental set-up for biohydrogen production}

The experimental set-up used consisted of $500 \mathrm{~mL}$ glass bottle, fabricated with rubber stoppers, and plastic valves along with a long tube. The reactor was sealed with paraffin wax to avoid gas leakage. The working volume of $400 \mathrm{~mL}$ was considered in all experiments. The long tube was connected with another vessel with an inlet and an outlet containing $10 \% \mathrm{NaOH}$. Total gas coming out from the reactor was purged into $\mathrm{NaOH}$ through the inlet for absorption of $\mathrm{CO}_{2}$. The biohydrogen gas produced was collected by downward displacement of water. The amount of water displaced was proportional to the amount of hydrogen produced. Pretreated seaweed was used as carbon source with external nutrients containing (/L): $2 \mathrm{~g}\left(\mathrm{NH}_{4}\right)_{2} \mathrm{SO}_{4}, 0.5 \mathrm{~g} \mathrm{NaCl}_{2}, 0.05 \mathrm{~g} \mathrm{MgSO}_{4}$, and $0.1 \mathrm{~g} \mathrm{~K}_{2} \mathrm{HPO}_{4}$ while the $\mathrm{pH}$ was adjusted to $6 \pm 0.5$. The mixed culture of the isolates grown in a synthetic medium was used as inoculam when it reached an optical density (OD) of $0.8 \pm 0.1$ at $620 \mathrm{~nm}$.

\subsection{Gas chromatography $(G C)$ analysis of produced hydrogen}

The amount of the produced hydrogen was estimated by injecting $500 \mu \mathrm{L}$ of the gas obtained from the reaction vessels with the help of a pressure lock gas syringe into a gas chromatograph (Chemito 7610 series GC) equipped with a Poropak Q column and a thermal conductivity detector. During gas analysis, the temperature of the column was set at $60^{\circ} \mathrm{C}$, injection port at $60^{\circ} \mathrm{C}$, and the detector at $90^{\circ} \mathrm{C}$. The nitrogen gas was selected as carrier gas at a flow rate of $30 \mathrm{~mL} / \mathrm{min}$.

Cumulative hydrogen gas production curves were constructed as previously described by Zhang and Shen (2007) by measuring the amount of hydrogen produced. Each cumulative hydrogen production curve was modelled using the modified Gompertz equation (Eq. 3)

$\mathrm{H}=\mathrm{P} \exp [-\exp [R m \cdot e / P(\lambda-\mathrm{t})+1]]$

where $\mathrm{H}$ is the cumulative hydrogen production $(\mathrm{mL}), \lambda$ is the lag time $(\mathrm{h})$, $\mathrm{P}$ stands for hydrogen production potential $(\mathrm{mL}), \mathrm{Rm}$ denotes the maximum hydrogen production rate $(\mathrm{mL} / \mathrm{h})$, and e is the constant value of 2.718281828 . This model is commonly used to describe the biological production of various gases such as methane and hydrogen in batch setups.

\subsection{Structural changes after pretreatment}

The changes in the structural and functional groups in seaweed before and after pretreatment with the best catalyst were studied by Fourier Transform InfraRed Spectroscopy (FTIR, PerkinElmer) with a Spectrum Version 10.03.09. A total of 4 scans were taken, with a resolution of $4 / \mathrm{cm}$, in the frequency range of $4000-400 / \mathrm{cm}$, in the transmission mode

$\mathrm{X}$-ray diffraction of the samples was studied to determine the changes in crystalline nature of the seaweed by using Panalytical X'Pert Powder $X^{\prime}$ Celerator Diffractometer instrument under the measurement range of 10 to $80^{\circ}$ in $2 \theta$. The crystallinity indices were calculated using the following equation based on the X-ray diffractograms $(\mathrm{Eq} .4)$ :

C.I $\left.=\left[\left(I_{020}-I_{\mathrm{am}}\right) / I_{020}\right)\right] \times 100$

where $I_{020}$ is the intensity for the crystalline portion of cellulose at about $2 \theta$ $=22.5^{\circ}$ and $I_{\text {am }}$ represents the amorphous portion at about $2 \theta=18^{\circ}$ (ye Lee et al., 2013).

\subsection{Analytical methods}

The physicochemical parameters such as protein, carbohydrate, percentage of ash, moisture, total solids, and volatile solids were estimated in dried seaweed samples. Extraction of sugars from the seaweed was carried out by the procedure described by Mian and Percival (1973) and was estimated by phenol sulphuric acid method (Dubois et al., 1956). Protein content was extracted and estimated by following the methods of Barbarino and Lourenço (2005) and Raymont et al. (1964). Other parameters like percentage of moisture, total solids, volatile solids, and ash were analysed by the method provided by NREL (Murugesan and Rajakumari, 2005). Fermentation spent was analysed for intermediate compounds production using HPLC (Shimadzu, LC-10AT VP) equipped with a C-18 column.

\section{Results and Discussion}

\subsection{Seed inoculum description}

The seed inoculum used for biohydrogen production was isolated from the sewage sludge. In a previous study, undefined bacterial consortium obtained from sewage sludge was used for biohydrogen production from a seaweed Laminaria japonica (Park et al., 2009). Whereas in the present study, five predominant colonies were isolated from sewage sludge and pure cultures were obtained by re-streaking. Preliminary identification of the isolates was done with biochemical and Gram's staining characteristics. Genus and species level identification were done by using MALDI-TOF mass spectrometry. This method has been materialized as an authentic method for rapid identification and classification of microorganisms (Seng et al., 2009). The isolates were screened using MALDI Biotyper. Highly probable species identification $\left(_{+++}\right)$was achieved with 3 species Bacillus cereus, B. megaterium, and Lysinibacillus boronitolerans. Secure genus identification and probable species identification were accomplished in two species Enterococcus spp. and B. subtilis. It is worth quoting that the MALDI-TOF analysis was used to study the differences within the Pantoea genus and segregated it into separate species with the same accuracy obtained using the 16s rRNA gene sequencing (Rezzonico et al., 2010). Comparable and reproducible classification of Vibrio species were also obtained by using the MALDI-TOF analysis and rpoB sequence analysis with very favourable resemblance (Dieckmann et al., 2010). The highquality separation of 92 strains of genetically-characterized Aeromonas at genospecies level was achieved using the MALDI-TOF analysis as well and the results were compared with those of gyrB gene sequencing showing a good agreement (Benagli et al., 2012).

Isolated colonies were screened for biohydrogen production (data not shown), and it was found that combined culture of the isolates were effective for biohydrogen production than individual cultures.

\subsection{Effect of different catalysts on total phenolic content and biohydrogen production}

The physicochemical properties of the collected $P$. tetrastromatica are presented in Table 2 . The seaweed sample contained nearly $44.78 \pm 1.12 \%$ of ash, reflecting the fact that it could be a good source mineral. $P$. tetrastromatica has been reported to be a rich source of carbohydrate, minerals, amino acids, and phycocolloids, e.g., fucoidan, alginic acid, and calcium alginate (Kamenarska et al., 2002). Although seaweeds are rich in carbohydrates, their inherent properties like crystallinity, polymerized carbohydrate content, and the presence of phenolic compounds (Audibert et al., 2010) make them resistant to microbial growth and consequently unsuitable for biofuels production. Several seaweeds have been studied for bio-ethanol and bio-methane production where different types of pretreatment methods were investigated to enhance the production rate of the product of interest (Horn et al., 2000; Bruhn et al., 2011; Jang et al., 2012; Sitompul et al., 2012)

Table 2.

Physicochemical properties of the seaweed Padina tetrastromatica.

\begin{tabular}{ll}
\hline Parameters & Content \\
\hline Ash $(\%)$ & $44.78 \pm 1.12$ \\
\hline Moisture $(\%)$ & $18.03 \pm 0.78$ \\
\hline Carbohydrate $(\mathrm{mg} / \mathrm{g})$ & $44.93 \pm 0.44$ \\
\hline Protein $(\mathrm{mg} / \mathrm{g})$ & $15.40 \pm 0.86$ \\
\hline Total solids $(\%)$ & $81.98 \pm 0.78$ \\
\hline Volatile solids $(\%)$ & $55.22 \pm 1.12$ \\
\hline Total phenolic content $(\mathrm{mg} \mathrm{GAE} / \mathrm{g})$ & $3.40 \pm 0.07$ \\
\hline
\end{tabular}


Considering the seaweed inhibitory challenges, selection of chemical catalysts for pretreatment experiments was conducted herein. Three mineral acid catalysts, including hydrochloric acid, sulphuric acid, and nitric acid, along with two base catalysts, i.e., sodium hydroxide and potassium hydroxide, were employed. Table 3 illustrates the effects of the catalysts on total phenolic content and biohydrogen production. Besides, the biomass conversion ratio was calculated. The most favourable results were obtained when the seaweed powder was treated with $1 \% \mathrm{H}_{2} \mathrm{SO}_{4}$. More specifically, phenolic compounds content was reduced to $1.6 \pm 0.07 \mathrm{mg} \mathrm{GAE} / \mathrm{g}$ compared with $3.4 \pm 0.07 \mathrm{mg}$ $\mathrm{GAE} / \mathrm{g}$ in raw seaweed. Moreover, biohydrogen production was increased to $78 \pm 2.9 \mathrm{~mL} / 0.05 \mathrm{~g}$ VS.

Biohydrogen production was much less $(34 \pm 4.8 \mathrm{~mL} / 0.05 \mathrm{~g}$ VS $)$ in the samples treated with nitric acid, most probably due to complete degradation of sugars. The sample treated with $\mathrm{HCl}$ produced biohydrogen at $38 \pm 4.1$ $\mathrm{ml} / 0.05 \mathrm{~g}$ VS. On the other hand, using the alkaline catalysts resulted in the formation of turbidity and after heating, white-coloured precipitate were formed which were very hard to neutralize. The biohydrogen production was also less than that of $1 \% \mathrm{H}_{2} \mathrm{SO}_{4}$, i.e., $42 \pm 3.6$ and $55 \pm 4.7 \mathrm{~mL} / 0.05 \mathrm{~g}$ VS for $2 \% \mathrm{KOH}$ and $2 \% \mathrm{NaOH}$, respectively. Jang et al. (2012) reported that dilute sulphuric acid extraction of Ulva lactuca resulted in increased sugars yield (49.32\% galactose, $12.62 \%$ glucose, and $31.53 \%$ mannitol) confirming that pretreatment was helpful in enhancing sugar availability. In a different investigation, pretreating the seaweed wastes from alginate producing industry with sulphuric acid led to increased cellulose content and glucose yield (Ge et al., 2011).

In terms of phenolic content removal, sulphuric acid pretreatment was found more efficient than $\mathrm{HCl}$ and $\mathrm{HNO}_{3}$ treatments as well as alkaline treatments (Table 3). Complete removal of phenolic content was not achieved with any of the treatments. Overall, it could be concluded that among the catalysts used, dilute $\mathrm{H}_{2} \mathrm{SO}_{4}$ was the most efficient catalyst in terms of phenolic content removal which consequently resulted in enhanced biohydrogen production. This catalyst was used in the subsequent experiments.

Table 3.

Details of catalyst and seaweed compositional changes.

\begin{tabular}{lccc}
\hline Catalyst & $\begin{array}{c}\text { Cumulative hydrogen } \\
\text { production }(\mathbf{m L})\end{array}$ & $\begin{array}{c}\text { Conversion } \\
\text { ratio }(\%)\end{array}$ & $\begin{array}{c}\text { Total phenolic content } \\
(\mathbf{m g} \text { GAE/g) }\end{array}$ \\
\hline Acids & & & \\
\hline $1 \% \mathrm{HCl}$ & $38 \pm 4.1$ & $8.0 \pm 0.59$ & $2.6 \pm 0.11$ \\
$1 \% \mathrm{HNO}_{3}$ & $34 \pm 4.8$ & $6.4 \pm 0.47$ & $2.8 \pm 0.12$ \\
$1 \% \mathrm{H}_{2} \mathrm{SO}_{4}$ & $78 \pm 2.9$ & $25.9 \pm 1.91$ & $1.6 \pm 0.07$ \\
\hline Bases & & & \\
\hline $2 \% \mathrm{KOH}$ & $42 \pm 3.6$ & $18.1 \pm 1.33$ & $1.8 \pm 0.08$ \\
$2 \% \mathrm{NaOH}$ & $55 \pm 4.7$ & $19.3 \pm 1.43$ & $2.1 \pm 0.09$ \\
\hline
\end{tabular}

3.3. Optimization of pretreatment for phenolic content removal and biohydrogen production

Along with the concentration of the selected catalyst, i.e., $\mathrm{H}_{2} \mathrm{SO}_{4}$, substrate concentration and reaction time, as important factors in the removal of phenolic content, were also investigated. The effects of these three variables and their interactions on phenolic removal from seaweed was studied by 20 runs (Table 4). The analysis of variance (ANOVA) and regressions for phenolic content removal showed that the model was properly fitted (Table 5). In the regression analysis, the experimental results showed that all the three variables and their interactions had positive linear effects $(\mathrm{P}<0.05)$ on the removal of phenol content. A second order polynomial equation could define the removal of phenolic content from the seaweed under different experimental conditions (Eq. 5).

Total phenolic content $(\mathrm{mg} \mathrm{GAE} / \mathrm{g})=0.065-0.43 \mathrm{~A}-0.20 \mathrm{~B}-0.43 \mathrm{C}-0.14 \mathrm{AB}$ $-0.24 \mathrm{AC}-0.31 \mathrm{BC}+0.92 \mathrm{~A}^{2}+0.64 \mathrm{~B}^{2}+0.34 \mathrm{C}^{2}$

The coefficient of significance was calculated for all the parameters (A, B, $\mathrm{C}, \mathrm{AB}, \mathrm{AC}, \mathrm{BC}, \mathrm{A}^{2}, \mathrm{~B}^{2}$, and $\mathrm{C}^{2}$ ) and the interactions among all factors showed
Table 4.

Central composite design for the optimization of phenolic content removal and hydrogen production.

\begin{tabular}{|c|c|c|c|c|c|}
\hline $\begin{array}{l}\text { Run } \\
\text { No. }\end{array}$ & $\begin{array}{c}\text { Substrate } \\
\text { concentration } \\
(\mathrm{g} / \mathrm{L})\end{array}$ & $\begin{array}{c}\text { Acid } \\
\text { concentration } \\
(\% \mathrm{v} / \mathrm{v})\end{array}$ & $\begin{array}{c}\text { Run } \\
\text { time } \\
\text { (h) }\end{array}$ & $\begin{array}{c}\text { Response 1: } \\
\text { Phenolic } \\
\text { content } \\
(\mathrm{mg} \mathrm{GAE} / \mathrm{g})\end{array}$ & $\begin{array}{c}\text { Response 2: } \\
\text { Hydrogen } \\
\text { production } \\
\text { (mL/0.05 g VS) }\end{array}$ \\
\hline 1 & 2.00 & 1.00 & 1.00 & 0.09 & 14.5 \\
\hline 2 & 2.00 & 1.00 & 0.16 & 1.80 & 11.3 \\
\hline 3 & 3.00 & 1.50 & 0.50 & 2.10 & 11.2 \\
\hline 4 & 1.00 & 0.50 & 1.50 & 2.60 & 11.5 \\
\hline 5 & 1.00 & 1.50 & 0.50 & 2.80 & 11.8 \\
\hline 6 & 3.00 & 1.50 & 1.50 & 0.20 & 11.6 \\
\hline 7 & 2.00 & 1.00 & 1.00 & 0.07 & 14.3 \\
\hline 8 & 2.00 & 1.00 & 1.00 & 0.01 & 14.1 \\
\hline 9 & 0.32 & 1.00 & 1.00 & 3.40 & 11.4 \\
\hline 10 & 3.00 & 0.50 & 1.50 & 1.50 & 13.5 \\
\hline 11 & 2.00 & 1.00 & 1.84 & 0.30 & 13.4 \\
\hline 12 & 2.00 & 1.00 & 1.00 & 0.06 & 13.9 \\
\hline 13 & 2.00 & 0.16 & 1.00 & 2.20 & 13.7 \\
\hline 14 & 3.68 & 1.00 & 1.00 & 2.00 & 13.8 \\
\hline 15 & 2.00 & 1.00 & 1.00 & 0.06 & 14.5 \\
\hline 16 & 3.00 & 0.50 & 0.50 & 2.20 & 12.7 \\
\hline 17 & 1.00 & 1.50 & 1.50 & 1.80 & 11.5 \\
\hline 18 & 1.00 & 0.50 & 0.50 & 2.30 & 12.3 \\
\hline 19 & 2.00 & 1.84 & 1.00 & 1.60 & 12.3 \\
\hline 20 & 2.00 & 1.00 & 1.00 & 0.09 & 13.6 \\
\hline
\end{tabular}

a low $\mathrm{P}$ value $(\mathrm{P}<0.05)$. The predicted $\mathrm{R}^{2}$ of 0.99 was in reasonable agreement with the adjusted $\mathrm{R}^{2}$ of 0.98 . The effect of interaction of different variables on phenolic content removal was clearly explained by $3 \mathrm{D}$ plots (Fig. 1). Therefore, it was found that the optimized factors for effective removal of phenolic content was substrate concentration of $2 \mathrm{~g} / \mathrm{L}, 1 \%$ $\mathrm{H}_{2} \mathrm{SO}_{4}$ acid, and the reaction time of $1 \mathrm{~h}$. Same pretreatment conditions (20 experiments given by the model) were studied for biohydrogen production (Table 4). Pretreated seaweed residues (neutralized) obtained from each experiment were used for biohydrogen production as explained earlier. Analysis of variance (ANOVA) and regressions for biohydrogen production showed that the model fitted well (Table 5). In regression analysis, the experimental results showed that substrate concentration and acid concentration had positive linear effects $(\mathrm{P}<0.05)$ on biohydrogen production. However, reaction time and interactions among the variables showed negative linear effects $(\mathrm{P}>0.05)$. The following second order polynomial equation could define biohydrogen production (Eq. 6):

Biohydrogen production $(\mathrm{mL} / \mathrm{L} / \mathrm{h})=14.17+0.43 \mathrm{~A}-0.46 \mathrm{~B}+0.27 \mathrm{C}-$ $0.36 \mathrm{AB}+0.29 \mathrm{AC}+0.013 \mathrm{BC}-0.66 \mathrm{~A}^{2}-0.52 \mathrm{~B}^{2}-0.75 \mathrm{C}^{2}$

(Eq. 6)

The response surface 3D plots clearly described the interactions among variables in biohydrogen production (Fig. 2). From the optimization results, it was found that the reaction time showed negative effects on hydrogen production even in small variations. Hence, the same optimized factors (2 $\mathrm{g} / \mathrm{L}$ substrate concentration, $1 \% \mathrm{v} / \mathrm{v}$ acid concentration, and $1 \mathrm{~h}$ reaction time) were found to be effective for pretreatment leading to enhanced biohydrogen production.

\subsection{Effect of pretreatment on compositional and structural changes}

ye Lee et al. (2013) claimed that the pretreatment of seaweed (Saccharina japonica) greatly influenced the structural and chemical composition of the seaweed by removing the non-cellulosic components such as alginate, mannitol, and ash. In the present study, chemical 
Table 5.

ANOVA of the regression model for phenolic content removal and biohydrogen production.

\begin{tabular}{|c|c|c|c|c|c|c|c|c|c|c|}
\hline \multirow[b]{2}{*}{ Source } & \multicolumn{5}{|c|}{ Response 1: Phenolic content removal } & \multicolumn{5}{|c|}{ Response 2: Biohydrogen production } \\
\hline & Sum of Squares & df & Mean Square & F Value & p-value $>$ F & Sum of Squares & df & Mean Square & F Value & p-value $>$ F \\
\hline Model & 24.03 & 9 & 2.67 & 1078.65 & $<0.0001$ & 23.59 & 9 & 2.62 & 7.09 & 0.0026 \\
\hline A-Substrate concentration $(\mathrm{g} / \mathrm{L})$ & 2.51 & 1 & 2.51 & 1014.08 & $<0.0001$ & 2.58 & 1 & 2.58 & 6.98 & 0.0247 \\
\hline B-Acid concentration $(\% \mathrm{v} / \mathrm{v})$ & 0.54 & 1 & 0.54 & 217.14 & $<0.0001$ & 2.86 & 1 & 2.86 & 7.75 & 0.0194 \\
\hline C-Reaction Time (h) & 2.48 & 1 & 2.48 & 1003.08 & $<0.0001$ & 0.97 & 1 & 0.97 & 2.61 & 0.1372 \\
\hline $\mathrm{AB}$ & 0.15 & 1 & 0.15 & 61.11 & $<0.0001$ & 1.05 & 1 & 1.05 & 2.84 & 0.1227 \\
\hline $\mathrm{AC}$ & 0.45 & 1 & 0.45 & 182.3 & $<0.0001$ & 0.66 & 1 & 0.66 & 1.79 & 0.211 \\
\hline $\mathrm{BC}$ & 0.78 & 1 & 0.78 & 315.7 & $<0.0001$ & 1.25 & 1 & 1.25 & 3.38 & 0.955 \\
\hline A2 & 12 & 1 & 12 & 4932.15 & $<0.0001$ & 6.3 & 1 & 6.3 & 17 & 0 \\
\hline B2 & 5.86 & 1 & 5.86 & 2366 & $<0.0001$ & 3.93 & 1 & 3.93 & 10.6 & 0.01 \\
\hline $\mathrm{C} 2$ & 1.64 & 1 & 1.64 & 661.2 & $<0.0001$ & 8.14 & 1 & 8.14 & 22.02 & 0.0009 \\
\hline Residual & 0.025 & 10 & 0.00248 & - & - & 3.7 & 10 & 0.37 & - & - \\
\hline Lack of Fit & 0.02 & 5 & 0.004 & 4.71 & 0.0571 & 3.06 & 5 & 0.61 & 4.82 & 0.0546 \\
\hline Pure Error & 0.004 & 5 & 0.0008 & - & - & 0.64 & 5 & 0.13 & - & - \\
\hline Cor Total & 24.05 & 19 & - & - & - & 27.29 & 19 & - & - & - \\
\hline
\end{tabular}
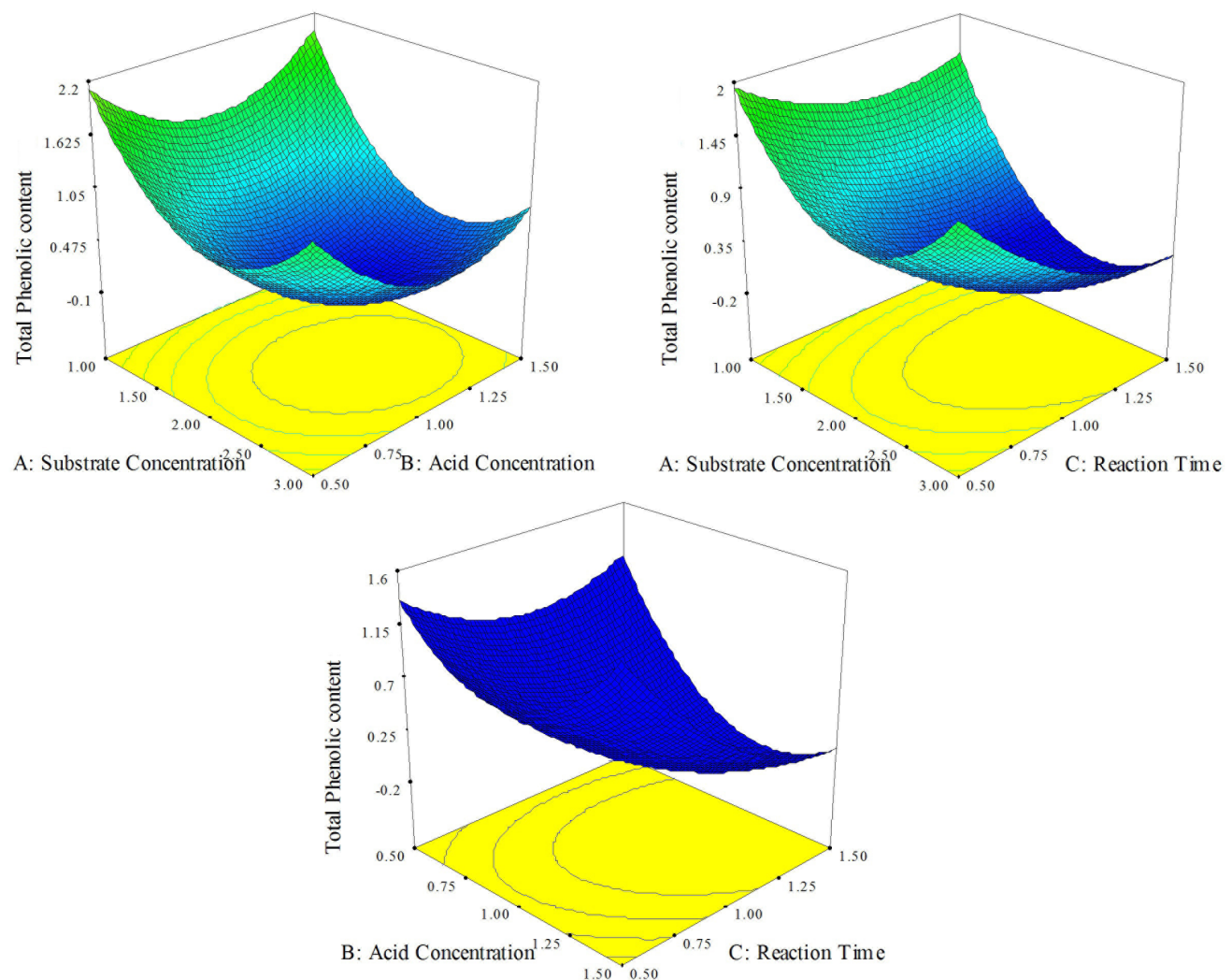

Fig.1. 3D quadratic plots showing the effects of the interactions among the variables on phenolic content. 
Fig.2. 3D quadratic plots showing the effects of the interactions among the variables on biohydrogen production.
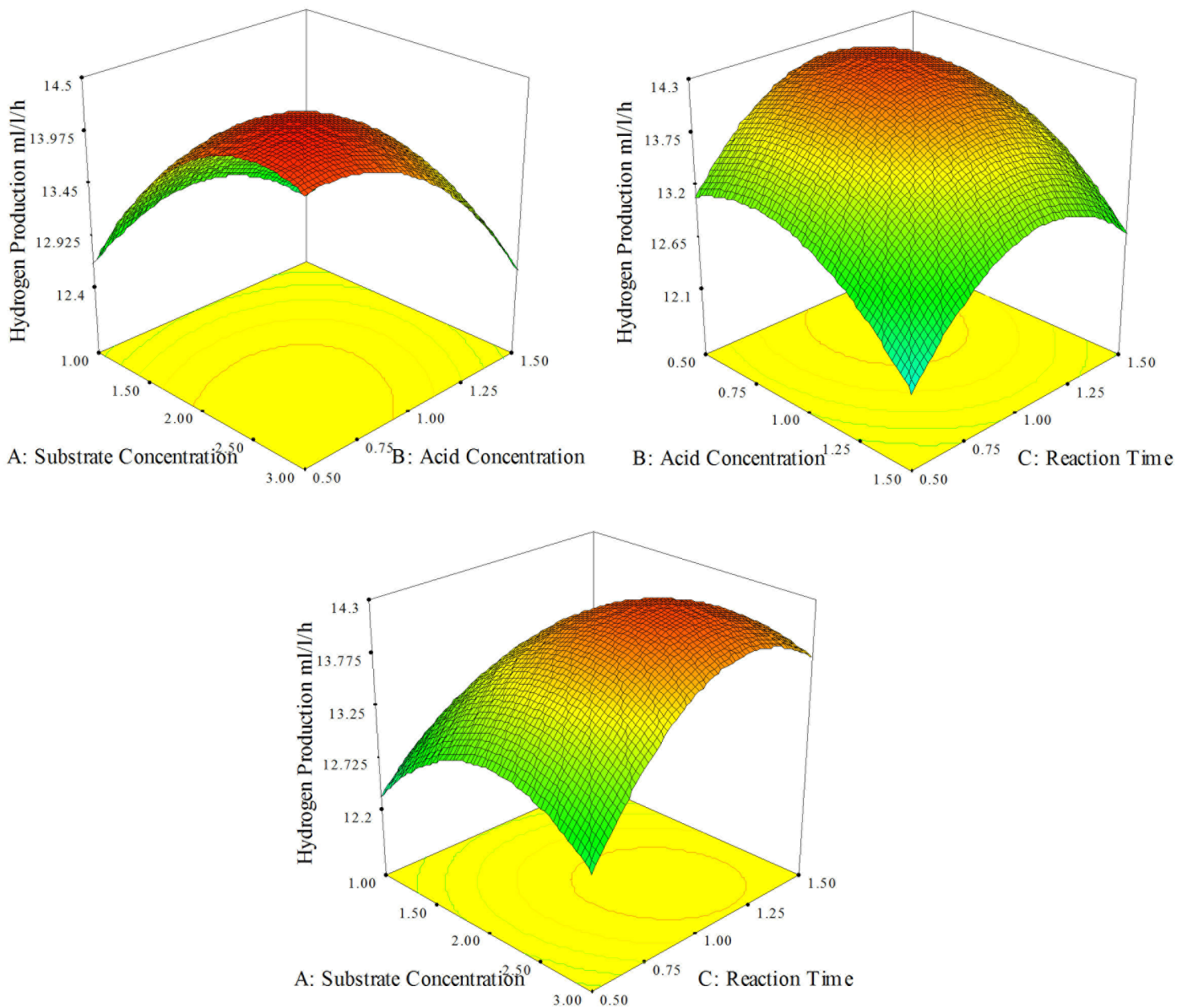

Table 6.

FTIR pattern of the seaweed sample.

\begin{tabular}{|c|c|c|c|}
\hline Wavenumber & Functional Group & Raw Seaweed & Pretreated Seaweed \\
\hline 3355 & -OH stretch of alcohols, phenols, -NH stretch of primary amines, amides & Present & Visible peaks were absent indicating groups modification \\
\hline 1632 & $\mathrm{~N}-\mathrm{H}$ bend of primary amines & Present & Present (wavenumber was slightly changed) \\
\hline 1459 & C-C stretch of aromatics & & \\
\hline 1428 & $\mathrm{C}-\mathrm{C}$ stretch of aromatics & Present & $\begin{array}{l}\text { Changes in the peaks representing particular groups were } \\
\text { observed }\end{array}$ \\
\hline 1236 & C-O stretch of alcohol, ethers, esters and carboxylic acids & & \\
\hline 1000 & $\begin{array}{l}\text { C-O stretch of alcohol, ethers, esters and carboxylic acids, =C-H bend of } \\
\text { alkenes }\end{array}$ & $\begin{array}{l}\text { Very broad spectrum of peak was } \\
\text { observed }\end{array}$ & Steep peak was observed \\
\hline 878 & $\mathrm{~N}-\mathrm{H}$ wag of primary and secondary amines, $\mathrm{C}-\mathrm{H}$ oop of aromatics & Present & Absent \\
\hline 517 & C-Br stretch of alkyl halides, & Present & Absent \\
\hline
\end{tabular}

composition and functional groups present in the seaweeds were determined by using FTIR spectroscopy. The FTIR spectrum of the raw and pretreated seaweed showed several intense peaks at different wavenumbers as shown in Table 6. The functional peak at $3355 \mathrm{~cm}^{-1}$ is attributed to the $-\mathrm{OH}$ stretch of alcohols, phenols, and to the $-\mathrm{NH}$ stretch of primary and secondary amines in the raw seaweed and these peaks were absent in the pretreated seaweed (Fig. 3). The N-H bend of primary amines were found at $1632 \mathrm{~cm}^{-1}$ and this particular peak was slightly modified after the pretreatment process. The $\mathrm{C}$ - 
$\mathrm{C}$ stretch of aromatics and C-O stretch of alcohol, ethers, esters, and carboxylic acids at 1459,1428 , and $1236 \mathrm{~cm}^{-1}$ were visible in raw seaweeds while in the pretreated material showed notable modifications. The peak observed at 1000 $\mathrm{cm}^{-1}$ was attributed to the $\mathrm{C}-\mathrm{O}$ stretch of alcohols, ethers, esters, and carboxylic acids and the $=\mathrm{C}-\mathrm{H}$ bend of alkenes was also observed in both samples. Overall, a very broad spectrum of peaks was observed in the raw seaweed while in the case of pretreated seaweed, steep peaks were observed. The intense peak at 878 $\mathrm{cm}^{-1}$ arises due to the presence of N-H wag of primary and secondary amines. The impurities present in the sample were represented by the $\mathrm{C}-\mathrm{Br}$ stretch of alkyl halides at $517 \mathrm{~cm}^{-1}$. Both these peaks were absent in the pretreated sample.

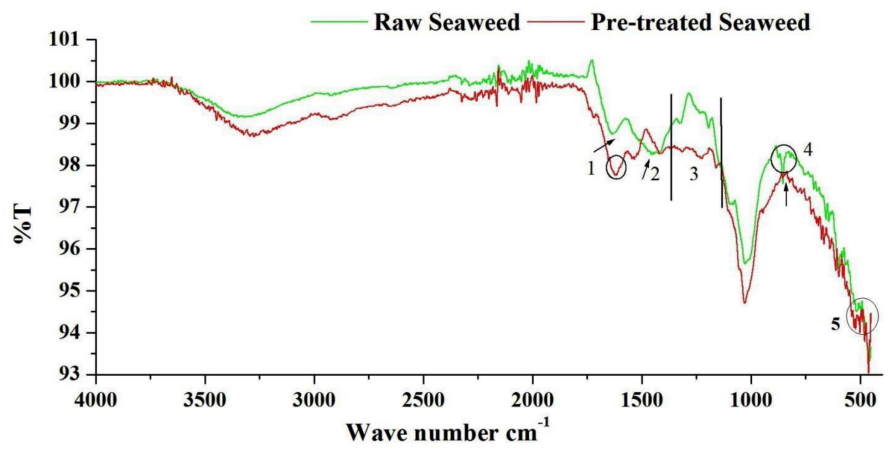

Fig. 3. The FTIR chromatograms of the raw and pretreated seaweed P. Tetrastromatica.
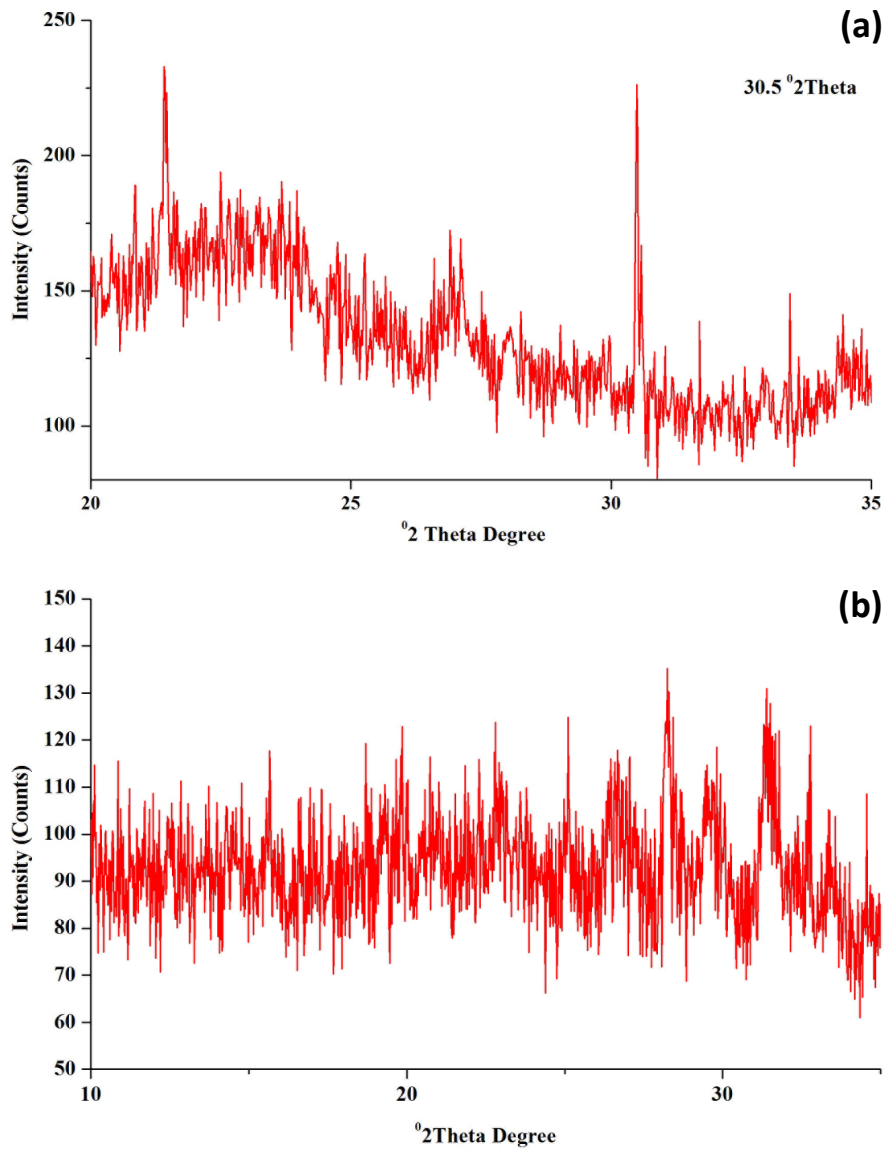

Fig.4. XRD profile for (a) before and (b) after pretreatment of $P$. Tetrastromatica.
The XRD patterns of the raw and the pretreated seaweed samples showed the featured diffraction peak at $30.5^{\circ}$ with inter planar spacing (d spacing) of 2.92775 and the calculated crystallinity index of 37.84 (Fig. 4). Whereas the pretreated sample showed no well-defined peaks and negative value in CrI indicating the amorphous nature of the sample. Crystallinity index of the substrate is an important characteristic to be studied to determine the availability of sugar through the hydrolysis of cellulosic materials (El-Sakhawy and Hassan, 2007). Roy et al. (2014) studied the effect of different pretreatment methods on CrI of microalgae and reported that the microalgae treated with acid catalyst showed a decreased crystallinity of 3.808 .

\subsection{Biohydrogen production kinetic}

The biohydrogen production profiles using the pretreated seaweed samples under optimized conditions are presented in Figure 5. At $24 \mathrm{~h}$ of incubation, biohydrogen production was increased with a significant decrease in sugar level. Biohydrogen production was sustained for $144 \mathrm{~h}(6$ d) but it subsequently decreased very significantly and after $8 \mathrm{~d}$, the production stopped. Biohydrogen production kinetic was studied based on Equation 3 indicating a hydrogen production potential $(P)$ of $6.3 \mathrm{~mL}$ and maximum hydrogen production rate $(R)$ of $4.2 \mathrm{~mL} / \mathrm{L} / \mathrm{h}$. Calculated cumulative hydrogen production $(H \mathrm{ml})$ stood at $15.9 \mathrm{~mL}$.

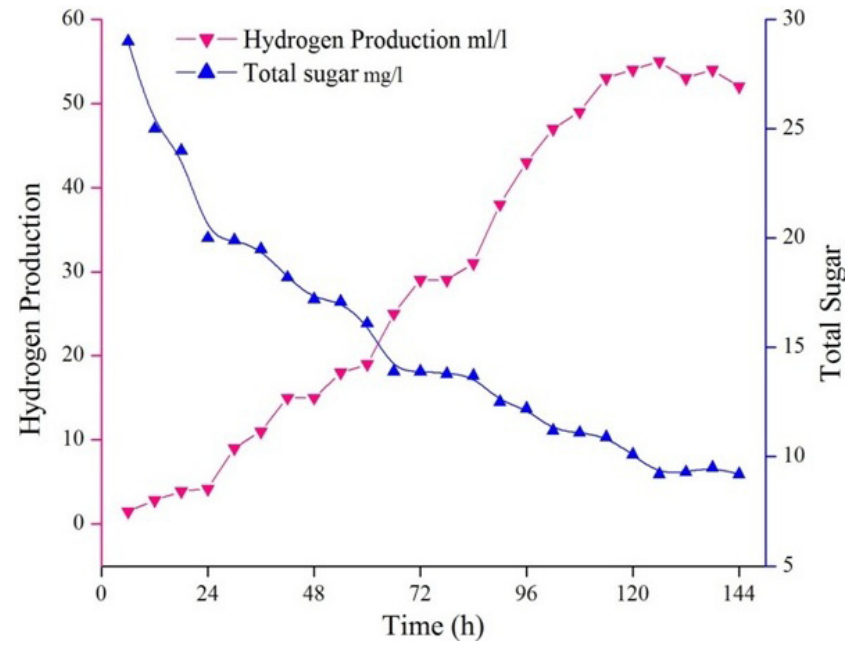

Fig.5. Reducing sugar exhaustion and biohydrogen production profile utilizing the pretreated seaweed.

\section{Conclusions}

The seaweed $P$. tetrastromatica was studied for its potential to produce biofuel. Chemical pretreatment enhanced the removal of phenolic content while simultaneously enhanced biohydrogen production. Among five different catalysts examined sulphuric acid considerably reduced the phenolic content and significantly increased biohydrogen production. Optimization of the pretreatment conditions for effective removal of phenolic content and enhanced biohydrogen production was accomplished with response surface methodology. Under optimized conditions, i.e., substrate concentration $2 \mathrm{~g} / \mathrm{L}(\mathrm{w} / \mathrm{v})$, acid concentration $1 \%(\mathrm{v} / \mathrm{v})$, and reaction time $1 \mathrm{~h}$, biohydrogen production was improved. Overall, the acid pretreatment of seaweed for the removal of phenolic content was effective and led to enhanced cumulative biohydrogen production $(78 \pm 2.9 \mathrm{~mL} / 0.05$ g VS).

\section{Acknowledgements}

The financial assistance of the Defence Research \& Development Organization (DRDO-GOI), Ministry of Defence, provided through a 
major research project to Prof. A.G. Murugesan is gratefully acknowledged. We also acknowledge the Department of Science and Technology for the DSTFIST Programme (S/FIST/ESI-101/2010).

\section{References}

[1] Adams, J.M., Gallagher, J.A., Donnison, I.S., 2009. Fermentation study on Saccharina latissima for bioethanol production considering variable pre-treatments. J. Appl. Phycol. 21(5), 569-574.

[2] Audibert, L., Fauchon, M., Blanc, N., Hauchard, D., Ar Gall, E., 2010. Phenolic compounds in the brown seaweed Ascophyllum nodosum: distribution and radical-scavenging activities. Phytochem. Anal. 21(5), 399-405.

[3] Bala-Amutha, K., Murugesan, A.G., 2013. Biohydrogen production using corn stalk employing Bacillus licheniformis MSU AGM 2 strain. Renew. Energy. 50, 621-627.

[4] Barbarino, E., Lourenço, S.O., 2005. An evaluation of methods for extraction and quantification of protein from marine macro-and microalgae. J. Appl. Phycol. 17(5), 447-460

[5] Benagli, C., Demarta, A., Caminada, A., Ziegler, D., Petrini, O., Tonolla, M., 2012. A rapid MALDI-TOF MS identification database at genospecies level for clinical and environmental Aeromonas strains. PLoS One.7(10), 48441.

[6] Bruhn, A., Dahl, J., Nielsen, H.B., Nikolaisen, L., Rasmussen, M.B., Markager, S., Olesen, B., Arias, C., Jensen, P.D., 2011. Bioenergy potential of Ulva lactuca: biomass yield, methane production and combustion. Bioresour. Technol. 102, 2595-2604.

[7] Carlsson, A.S., Beilen, J.V., Möller, R., Clayton, D., 2007. Micro-and macro-algae: utility for industrial applications: outputs from the EPOBIO project. CPL Press

[8] Dieckmann, R., Strauch, E., Alter, T., 2010. Rapid identification and characterization of Vibrio species using whole-cell MALDI-TOF mass spectrometry. J. Appl. Microbiol. 109(1), 199-211.

[9] Dubois, M., Gilles, K.A., Hamilton, J.K., Rebers, P.A.T., Smith, F., 1956. Colorimetric method for determination of sugars and related substances. Anal. Chem. 28, 350-356.

[10] El-Sakhawy, M., Hassan, M.L., 2007. Physical and mechanical properties of microcrystalline cellulose prepared from agricultural residues. Carbohydr. Polym. 67(1), 1-10

[11] Ge, L., Wang, P., Mou, H., 2011. Study on saccharification techniques of seaweed wastes for the transformation of ethanol. Renew. Energy. 36(1), 84-89.

[12] Hallenbeck, P.C., Abo-Hashesh, M., Ghosh, D., 2012. Strategies for improving biological hydrogen production. Bioresour. Technol. 110, 1-9.

[13] Horn, S., Aasen, I., Østgaard, K., 2000. Ethanol production from seaweed extract. J. Ind. Microbiol. Biotechnol. 25(5), 249-54.

[14] Jang, J.S., Cho, Y., Jeong, G.T., Kim, S.K., 2012. Optimization of saccharification and ethanol production by simultaneous saccharification and fermentation (SSF) from seaweed, Saccharina japonica. Bioprocess. Biosyst. Eng. 35(1), 11-18

[15] Kamenarska, Z., Gasic, M.J., Zlatovic, M., Rasovic, A., Sladic, D., Kljajic, Z., Stefanov, K., Seizova, K., Najdenski, H., Kujumgiev, A., Tsvetkova, I., 2002. Chemical composition of the brown alga Padina pavonia (L.) Gaill. from the Adriatic Sea. Botanica Marina. 45(4), 339345

[16] Kapdan, I.K., Kargi, F., 2006. Bio-hydrogen production from waste materials. Enzyme Microb. Technol. 38(5), 569-582

[17] Lakshmikandan, M., Murugesan, A.G., 2016a. Enhancement of growth and biohydrogen production potential of Chlorella vulgaris MSU-AGM 14 by utilizing seaweed aqueous extract of Valoniopsis pachynema. Renew. Energy, 96, 390-399

[18] Lakshmikandan, M., Murugesan, A.G., 2016b. Chlorella vulgaris MSUAGM 14, a fresh water micro algal strain - growth and photobiological hydrogen production in acid hydrolysate of seaweed Valoniopsis pachynema. Int. J. Hydrogen Energy. 41(32), 13986-13992.

[19] Leu, S., Boussiba, S., 2014. Advances in the production of high-value products by microalgae. Ind. Biotechnol. 10(3), 169-183.
[20] Liu, R.H., 2003. Health benefits of fruit and vegetables are from additive and synergistic combinations of phytochemicals. Am. J. Clin. Nutr. 78(3), 517S-520S

[21] Li, Y., Ren, N., Yang, C., Chen, Y., Li, J., Zheng, G., 2004 Biohydrogen production behaviour and molecular characterization of a new species of anaerobic bacterium. Anaerobic Digestion. 648-653.

[22] Lu, X., Zhang, Y., Angelidaki, I., 2009. Optimization of H2SO4. catalyzed hydrothermal pretreatment of rapeseed straw for bioconversion to ethanol: focusing on pretreatment at high solids content. Bioresour. Technol. 100(12), 3048-3053.

[23] Mian, A.J., Percival, E., 1973. Carbohydrates of the brown seaweeds himanthalia lorea, bifurcaria bifurcata, and Padina pavonia: part I. extraction and fractionation. Carbohydr. Res. 26(1), 133-146.

[24] Milledge, J.J., Smith, B., Dyer, P.W, Harvey, P., 2014. Macroalgaederived biofuel: a review of methods of energy extraction from seaweed biomass. Energies. 7(11), 7194-7222.

[25] Murugesan, A.G., Rajakumari, C., 2005. Environmental Science and Biotechnology: Theory and Techniques. MUP Publishers

[26] Park, J.I., Lee, J., Sim, S.J., Lee, J.H., 2009. Production of hydrogen from marine macro-algae biomass using anaerobic sewage sludge microflora. Biotechnol. Bioprocess Eng. 14(3), 307-315.

[27] Podsędek, A., 2007. Natural antioxidants and antioxidant capacity of Brassica vegetables: a review. LWT Food Sci. Technol. 40(1), 1-11.

[28] Rajkumar, R., Yaakob, Z., Takriff, M.S., 2013. Potential of micro and macro algae for biofuel production: a brief review. Bioresources. 9(1), $1606-1633$

[29] Raymont, J.E.G., Austin, J., Linford, E., 1964. Biochemical studies on marine zooplankton I. The biochemical composition of Neomysis integer. Journal du Conseil. 28(3), 354-363.

[30] Ren, N., Li, J., Li, B., Wang, Y., Liu, S., 2006. Biohydrogen production from molasses by anaerobic fermentation with a pilotscale bioreactor system. Int. J. Hydrogen Energy. 31(15), 2147-2157.

[31] Rezzonico, F., Vogel, G., Duffy, B., Tonolla, M., 2010. Application of whole-cell matrix-assisted laser desorption ionization-time of flight mass spectrometry for rapid identification and clustering analysis of Pantoea species. Appl. Environ. Microbiol. 76(13), 4497-4509.

[32] Seng, P., Drancourt, M., Gouriet, F., La Scola, B., Fournier, P.E. Rolain, J.M., Raoult, D., 2009. Ongoing revolution in bacteriology: routine identification of bacteria by matrix-assisted laser desorption ionization time-of-flight mass spectrometry. Clin. Infect. Dis. 49(4), 543-551.

[33] Sitompul, J.P., Bayu, A., Soerawidjaja, T.H., Lee, H.W., 2013. Studies of biogas production from green seaweeds. J. Enveron. Bioenerg. 3(3), 132-144.

[34] Van der Wal, H., Sperber, B.L., Houweling-Tan, B., Bakker, R.R., Brandenburg, W., López-Contreras, A.M., 2013. Production of acetone, butanol, and ethanol from biomass of the green seaweed Ulva lactuca. Bioresour. Technol. 128, 431-437.

[35] Vaquero, M.J.R., Alberto, M.R., de Nadra, M.M., 2007. Antibacterial effect of phenolic compounds from different wines. Food Control. 18(2), 93-101.

[36] Vergara-Fernández, A., Vargas, G., Alarcón, N., Velasco, A., 2008. Evaluation of marine algae as a source of biogas in a two-stage anaerobic reactor system. Biomass Bioenergy. 32(4), 338-344.

[37] ye Lee, J., Li, P., Lee, J., Ryu, H.J., Oh, K.K., 2013. Ethanol production from Saccharina japonica using an optimized extremely low acid pretreatment followed by simultaneous saccharification and fermentation. Bioresour. Technol. 127, 119-125.

[38] Zhang, Y., Shen, J., 2007. Enhancement effect of gold nanoparticles on biohydrogen production from artificial wastewater. Int. J. Hydrogen Energy. 32(1), 17-23. 